\title{
Spatial Pattern of Trees Affected by Black Spot in Citrus Groves in Brazil
}

\author{
M. B. Spósito, Departamento Científico, Fundecitrus, C.P. 391, 14801-970, Araraquara, SP, Brazil; L. Amorim, De- \\ partamento de Entomologia, Fitopatologia e Zoologia Agrícola, ESALQ-USP, C.P. 9, 13418-900, Piracicaba, SP, \\ Brazil; P. J. Ribeiro, Jr., Departamento de Estatística, UFPR, C.P. 19.081, 81.531-990, Curitiba, PR, Brazil; \\ R. B. Bassanezi, Departamento Científico, Fundecitrus, Brazil; and E. T. Krainski, Departamento de Estatística, \\ UFPR, Brazil
}

\begin{abstract}
Spósito, M. B., Amorim, L., Ribeiro, P. J., Jr., Bassanezi, R. B., and Krainski, E. T. 2007. Spatial pattern of trees affected by black spot in citrus groves in Brazil. Plant Dis. 91:36-40.

Citrus black spot (CBS), caused by Guignardia citricarpa, is the most important fungal disease of orange trees in Brazil. The spatial pattern of CBS-symptomatic trees was evaluated using the binomial dispersion index $(D)$, Ripley's $\mathrm{K}$ function $(\mathrm{K})$, and a Monte Carlo test for minimum mean distance $(d)$ to understand the distribution of the pathogen. Disease was monitored in 7,790 citrus trees from four commercial groves. In one grove, disease incidence was assessed from 1999 to 2001 and, in the others, disease assessments were conducted only in 2002. Infected trees were aggregated based on the three statistical analyses used $(D, \mathrm{~K}$, and $d)$ regardless of the CBS incidence. The binomial index of dispersion $(D)$ indicated aggregation of CBS-affected trees for all groves and for various quadrat sizes ( 2 by 2,3 by 3,4 by $4 \ldots$ up to 10 by 10). According to Ripley's K function, the dependence among symptomatic trees comprised two to three neighboring trees. Disease dispersion occurred at distances below $24.7 \mathrm{~m}$ according to the test for $d$. This suggests that the dispersion of inoculum is highly important over short distances. As a consequence, the required sample size to achieve a level of accuracy of $\mathrm{C}=20 \%$ increases exponentially with the decrease in incidence of CBS below $15 \%$ infected plants.
\end{abstract}

Additional keywords: Phyllosticta citricarpa
Citrus black spot (CBS), caused by Guignardia citricarpa Kiely (anamorph Phyllosticta citricarpa (McAlpine) van der Aa), affects sweet orange, lemon, and tangerine and its hybrids (19). The most frequent symptoms are hard-spot lesions: necrotic, round spots up to $5 \mathrm{~mm}$ in diameter surrounded by a black margin. The disease affects the outer peel but does not change the internal quality of the fruit (7). Diseased fruit are unacceptable for fresh market, but can be used for processing (19). CBS also may cause premature fruit drop, thereby reducing production (18). If not properly controlled, CBS may cause up to a $50 \%$ reduction in yield (27).

CBS occurs in Africa, Asia, Oceania, and South America (1) and is classified as an A1 quarantine disease in the European Union, which has reduced the volume of imported citrus fruit from the areas where CBS has been detected (1). CBS was reported in 1992 in southeastern Brazil in the State of São Paulo (11). This state produces $80 \%$ of the domestic production

E-mail: marcel@fundecitrus.com.br

Accepted for publication 14 August 2006.

DOI: 10.1094/PD-91-0036

(C) 2007 The American Phytopathological Society
Corresponding author: M. B. Spósito
(13.5 million tons of fruit in 2004) and is the world's largest citrus-producing region (9). Less than $1 \%$ of this total is exported, primarily due to the presence of CBS in the groves in the State of São Paulo. The disease is still spreading through São Paulo; however, there are regions where the disease has not yet been found. Monitoring of the disease in the state is necessary in order to establish areas where disease incidence is low. A successful survey requires a good sampling program, and the description of spatial characteristics of diseased trees is essential for designing sampling programs (4).

Disease spatial patterns depend on the dispersion characteristics of the pathogen, the architecture of the host plants, and the configuration of these plants in the orchard (10). G. citricarpa produces ascospores in pseudothecia formed on decomposing citrus leaves on the ground. Ascospores are released during rainfall events and are dispersed by wind. Conidia are produced in pycnidia formed on fruit, leaves, and twigs and dispersed by water (28). Pathogens dispersed by wind, as a rule, spread long distances in a short period of time $(2,22)$, whereas rain-splash-dispersed pathogens reach mostly short distances around primary foci $(14,20)$

The objectives of the present study were to characterize the spatial pattern of CBS in commercial groves, quantify the level of dependence between symptomatic trees, and determine the sample size for estimating the incidence of the disease.

\section{MATERIALS AND METHODS}

Data collection. Disease assessments were conducted in four different groves in the State of São Paulo, yearly from 1999 to 2001 for grove I and in 2002 only for groves II to IV (Table 1). The incidence of trees with CBS was assessed just prior to harvest at a time when most of quiescent symptoms had appeared. Because disease symptoms appear on the exposed side of the fruit (1), all fruit of each tree were examined visually by walking down the rows. When even a single fruit with symptoms was detected, the tree was considered diseased. The location of each of the symptomatic trees was plotted on grove maps representing each grove.

Spatial statistics analysis. The spatial pattern of the symptomatic trees on the groves was analyzed by the binomial dispersion index $(D ; 21)$, Ripley's $\mathrm{K}$ function for spatial point pattern analysis $(\mathrm{K} ; 24)$, and a Monte Carlo test for the minimum mean distance $(d)$ to the nearest symptomatic tree.

The assessed areas were divided into quadrats of 2 by 2,3 by 3,4 by 4,5 by 5,6 by 6,7 by 7,8 by 8,9 by 9 , and 10 by 10 trees for the analyses using the dispersion
Table 1. Characteristics of four sweet orange groves surveyed in the State of São Paulo, Brazil, for citrus black spot, caused by Guignardia citricarpa

\begin{tabular}{llccc}
\hline Grove & $\begin{array}{c}\text { Cultivar/rootstock } \\
\text { combination }^{\mathbf{a}}\end{array}$ & $\begin{array}{c}\text { No. of } \\
\text { trees }\end{array}$ & $\begin{array}{c}\text { Year of } \\
\text { planting }\end{array}$ & $\begin{array}{c}\text { Tree spacing } \\
(\mathbf{m})\end{array}$ \\
\hline I & Natal/Cleopatra & 2,533 & 1984 & 9.0 by 6.0 \\
II & Valencia/Rangpur lime & 1,241 & 1993 & 7.0 by 4.0 \\
III & Valencia/Rangpur lime & 990 & 1984 & 7.5 by 5.5 \\
IV & Natal/Cleopatra & 3,026 & 1990 & 8.0 by 5.0 \\
\hline
\end{tabular}

a Natal and Valencia sweet orange (Citrus sinensis (L.) Osb.), Cleopatra mandarim (C. reshni Hort), and Rangpur lime (C. limonia Osbeck). 
index $(D)$. The incidence of symptomatic trees was estimated by $p=\Sigma X_{i} / n N$, where $X_{i}$ is the number of trees with symptomatic fruit affected by the CBS in the $i$ th quadrat, $n$ is the number of trees per quadrat, and $N$ is the total number of quadrats (21). Binomial variance $\left(V_{\text {bin }}\right)$ was determined by $V_{\text {bin }}=p(1-p) / n$ and observed variance $\left(V_{\text {obs }}\right)$ was calculated by (15):

$$
V_{o b s}=\sum_{i=1}^{N}\left(x_{i}-n p\right)^{2} / n^{2}(N-1)
$$

$D$ was obtained by $D=V_{\text {obs }} / V_{\text {bin }}$ (12) and, for each assessment, the value of $D$ was tested against the $\chi^{2}$ using $P=0.05$ as the significance level. When $D$ was equal to 1 , CBS was assumed to be randomly distributed through the area; whereas, when $D$ was greater than 1.0, CBS was assumed to be aggregated (21).

Ripley's K function of point pattern analysis adopts a different strategy by avoiding the subjective choice of quadrat sizes. This analysis assumed that the localization of the CBS-affected trees followed a point process. A spatial point process is a set of locations irregularly distributed within a designated region and is presumed to have been generated by some form of stochastic mechanism (6). Ripley's K function verified the density of CBS-affected trees in each area by the variance as a function of radial distances $(h)$ from the symptomatic trees. Ripley's K function was calculated using the formula $\mathrm{K}(h)=$ $E \lambda^{-1}$, where $\lambda$ is the density of the events or the mean number of symptomatic trees per area unit, and $E$ is the number of symptomatic trees within a unit area defined by the distance $h$ from a randomly chosen symptomatic tree. The $\mathrm{K}(h)$ function then was estimated by

$$
K(h)=\frac{\lambda^{-1} \sum_{i=1}^{n} \sum_{j=1}^{n} I_{h}\left(E_{i}, E_{j}\right)}{n} \text { for } i \neq j \text { and } h>0
$$

where $I_{h}$ is the function indicator and $n$ is the number of events. $I_{h}$ is 1 if $E_{j}$ is within the $h$ distance of the $E_{i}$; if $E_{j}$ is not within the $h$ distance of the $E_{i}$, then $I_{h}$ is 0 .

When the spatial localization of the symptomatic trees is independent, the process is random in space and $K(h)=\pi h^{2}$. For aggregated patterns, $K(h)>\pi h^{2}$; for regular patterns, $K(h)<\pi h^{2}$. The following normalization of Ripley's $\mathrm{K}$ function $(L(h))$ facilitates the graphic interpretation, given that the plot of the function is a horizontal line under spatial randomness; positive values indicate spatial attraction (aggregation) and negative values indicate repulsion or regularity (17).

Table 2. Percentage of quadrats with at least one tree with citrus black spot $(P)$, caused by Guignardia citricarpa, in grove I, and the binomial dispersion index $(D)$ for different combinations of quadrat

\begin{tabular}{|c|c|c|c|c|c|c|c|}
\hline \multirow[b]{3}{*}{ Quad $^{\text {b }}$} & \multirow[b]{3}{*}{ No. quad } & \multicolumn{6}{|c|}{ Grove $\mathbf{I}^{\mathbf{a}}$} \\
\hline & & \multicolumn{2}{|c|}{1999} & \multicolumn{2}{|c|}{2000} & \multicolumn{2}{|c|}{2001} \\
\hline & & $P$ & $D$ & $P$ & $D$ & $P$ & $D$ \\
\hline 2 by 2 & 360 & 10.5 & $1.1 \mathrm{~ns}$ & 23.2 & $1.3 *$ & 86.3 & $1.0 \mathrm{~ns}$ \\
\hline 3 by 3 & 144 & 10.7 & $1.1 \mathrm{~ns}$ & 24.3 & $1.7 *$ & 86.3 & $1.2 *$ \\
\hline 4 by 4 & 90 & 10.5 & $1.2 \mathrm{~ns}$ & 23.2 & $1.6 *$ & 86.3 & $1.4 *$ \\
\hline 5 by 5 & 56 & 10.4 & $1.1 \mathrm{~ns}$ & 23.2 & $1.7 *$ & 86.4 & $1.4 *$ \\
\hline 6 by 6 & 36 & 10.7 & $1.4 \mathrm{~ns}$ & 24.3 & $1.4 \mathrm{~ns}$ & 86.3 & $1.6 *$ \\
\hline 7 by 7 & 20 & 10.8 & $2.2 *$ & 24.5 & $1.8 *$ & 87.4 & $1.6 *$ \\
\hline 8 by 8 & 18 & 11.1 & $1.4 \mathrm{~ns}$ & 24.3 & $1.6 *$ & 86.1 & $1.8 *$ \\
\hline 9 by 9 & 16 & 10.7 & $0.9 \mathrm{~ns}$ & 24.3 & $1.5 \mathrm{~ns}$ & 86.3 & $2.2 *$ \\
\hline 10 by 10 & 14 & 10.4 & $1.7 *$ & 23.2 & $0.9 \mathrm{~ns}$ & 86.4 & $1.8 *$ \\
\hline
\end{tabular}
sizes for the 3 years studied

${ }^{\mathrm{a}}$ For trees inside the quadrat, $\mathrm{ns}=$ random pattern of symptomatic trees and $*=$ aggregated pattern of symptomatic trees.

${ }^{\mathrm{b}}$ Quadrat size, number of trees within rows by number of trees between rows.

${ }^{\mathrm{c}}$ Number of quadrats built inside the area.

$$
L(h)=\sqrt{\frac{K(h)}{\pi h^{2}}}-h
$$

"Envelopes" obtained by Monte Carlo simulations were built for the $\mathrm{K}$ or $L$ functions in order to test against the null hypothesis of spatial randomness. The values within the "envelope" represent the regions in which the hypothesis of a spatial randomness is not discarded (17). Additionally, the $\mathrm{K}$ function provides information on the approximated values for cluster sizes or distances between trees for regular patterns. $L(h)$ functions and envelopes for the incidence of symptomatic trees in the evaluated groves were computed by using the splancs (25) package written for $\mathrm{R}$ software (23).

A third test also was used to determine spatial aggregation. For every symptomatic tree, the distance to the nearest symptomatic tree was measured and the mean distance $(d)$ was calculated. For aggregated patterns, the mean distance is lower than under spatial randomness. Following that, a Monte Carlo analysis was used, where the sampling distribution of $d$ was obtained by simulating spatial randomness under the null hypothesis. The descriptive level of the test ( $P$ value) is given by the number of simulations where $d$ is equal to or higher than $d$ from the original data. We have written our own code to perform this process using the $\mathrm{R}$ language (23), using 1,000 simulations for grove I and 10,000 simulations each for groves II, III, and IV.

Sample size. Data from groves I, II, III, and IV for each year were used to establish the minimum sample size to estimate CBS incidence. Sample size (number of trees to be examined) was calculated using the following equation, in which reliability is defined by the coefficient of variability, adjusted to the negative binomial model (4):

$$
n=\frac{k+x}{x \cdot k \cdot C^{2}}
$$

where $n$ is the number of sample points needed to estimate the incidence of symptomatic trees in a particular area, $x$ is the average of incidence of symptomatic trees

\begin{tabular}{|c|c|c|c|c|c|c|c|c|c|}
\hline \multirow[b]{2}{*}{ Quadrat size $^{b}$} & \multicolumn{3}{|c|}{ Grove II $^{\mathrm{a}}$} & \multicolumn{3}{|c|}{ Grove III ${ }^{\mathbf{a}}$} & \multicolumn{3}{|c|}{ Grove IV ${ }^{a}$} \\
\hline & No. ${ }^{c}$ & $\boldsymbol{P}$ & $D$ & No. & $\boldsymbol{P}$ & $D$ & No. & $\boldsymbol{P}$ & $D$ \\
\hline 2 by 2 & 240 & 5.6 & $1.2 *$ & 184 & 19.6 & $1.8 *$ & 588 & 0.7 & $1.4 *$ \\
\hline 3 by 3 & 96 & 5.6 & $1.3 *$ & 77 & 19.6 & $3.2 *$ & 266 & 0.7 & $1.3 *$ \\
\hline 4 by 4 & 60 & 5.6 & $1.3 \mathrm{~ns}$ & 40 & 19.6 & $4.2 *$ & 140 & 0.7 & $1.6 *$ \\
\hline 5 by 5 & 36 & 5.6 & $1.0 \mathrm{~ns}$ & 28 & 19.6 & $5.9 *$ & 88 & 0.7 & $1.5 *$ \\
\hline 6 by 6 & 24 & 5.6 & $1.6 *$ & 15 & 19.6 & $7.7 *$ & 63 & 0.7 & $1.6 *$ \\
\hline 7 by 7 & 12 & 5.6 & $1.6 \mathrm{~ns}$ & 15 & 19.6 & $9.3 *$ & 48 & 0.7 & $2.0 *$ \\
\hline 8 by 8 & 12 & 5.6 & $1.5 \mathrm{~ns}$ & 8 & 19.6 & $10.2 *$ & 35 & 0.7 & $1.7 *$ \\
\hline 9 by 9 & 10 & 5.6 & $1.2 \mathrm{~ns}$ & 6 & 19.6 & $13.3 *$ & 24 & 0.7 & $1.8 *$ \\
\hline 10 by 10 & 8 & 5.6 & $1.5 \mathrm{~ns}$ & 6 & 19.6 & $22.7 *$ & 20 & 0.7 & $1.5 \mathrm{~ns}$ \\
\hline
\end{tabular}
in a particular area, $C^{2}$ is the rate of the

Table 3. Percentage of quadrats with at least one tree with citrus black spot $(P)$, caused by Guignardia citricarpa, in groves II, III, and IV, and the respective binomial dispersion indexes $(D)$ for different combinations of quadrat sizes in 2002

${ }^{\text {a }}$ For trees inside the quadrat, $\mathrm{ns}=$ random pattern of symptomatic trees and $*=$ aggregated pattern of symptomatic trees.

${ }^{\mathrm{b}}$ Quadrat size, number of trees within rows by number of trees between rows.

c No. $=$ number of quadrats built inside the area. 

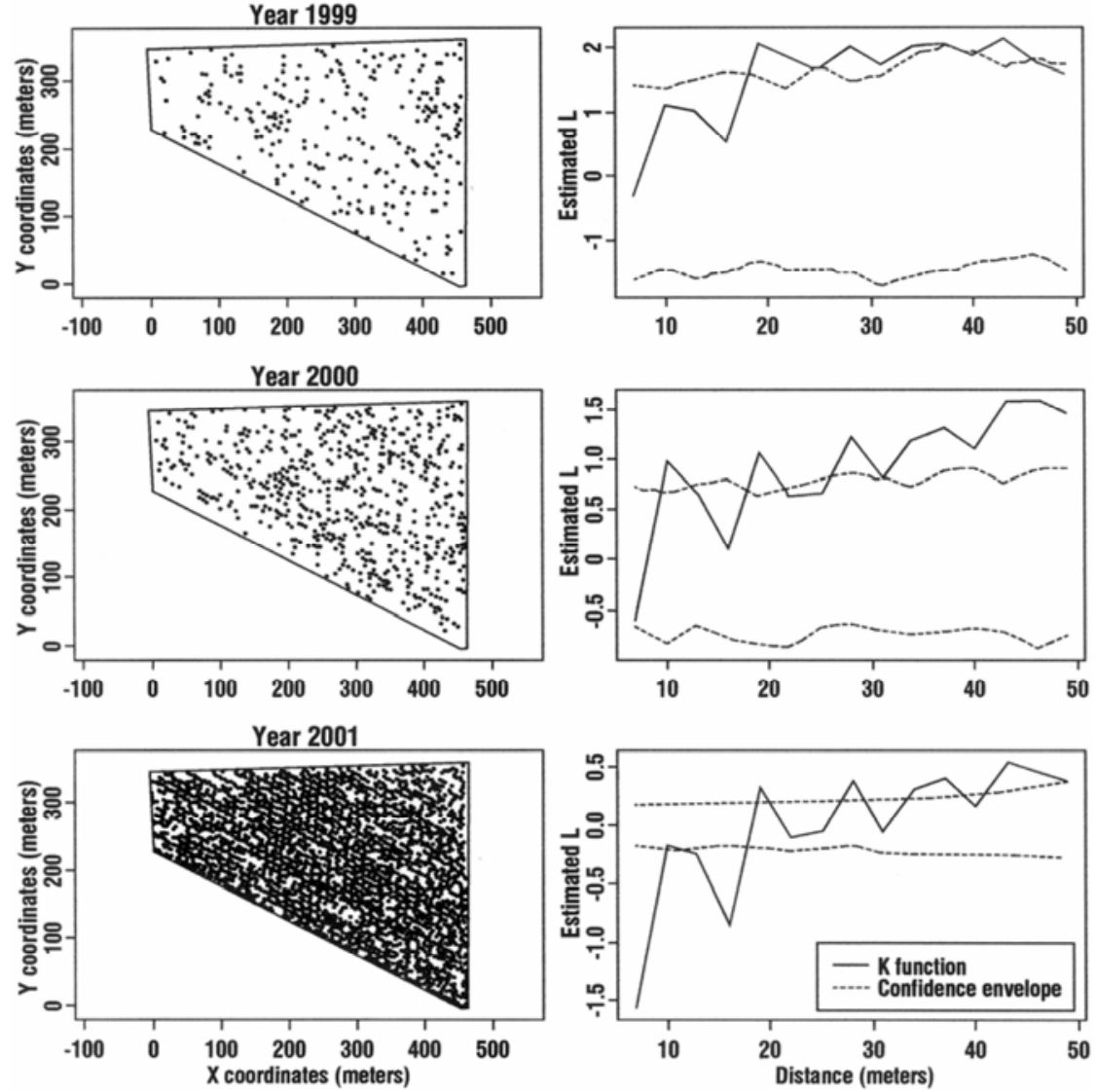

Fig. 1. Distribution of trees with fruit affected by citrus black spot, caused by Guignardia citricarpa, and Ripley's K function fit in grove I for 1999, 2000, and 2001. Values above the confidence envelope indicate aggregation.
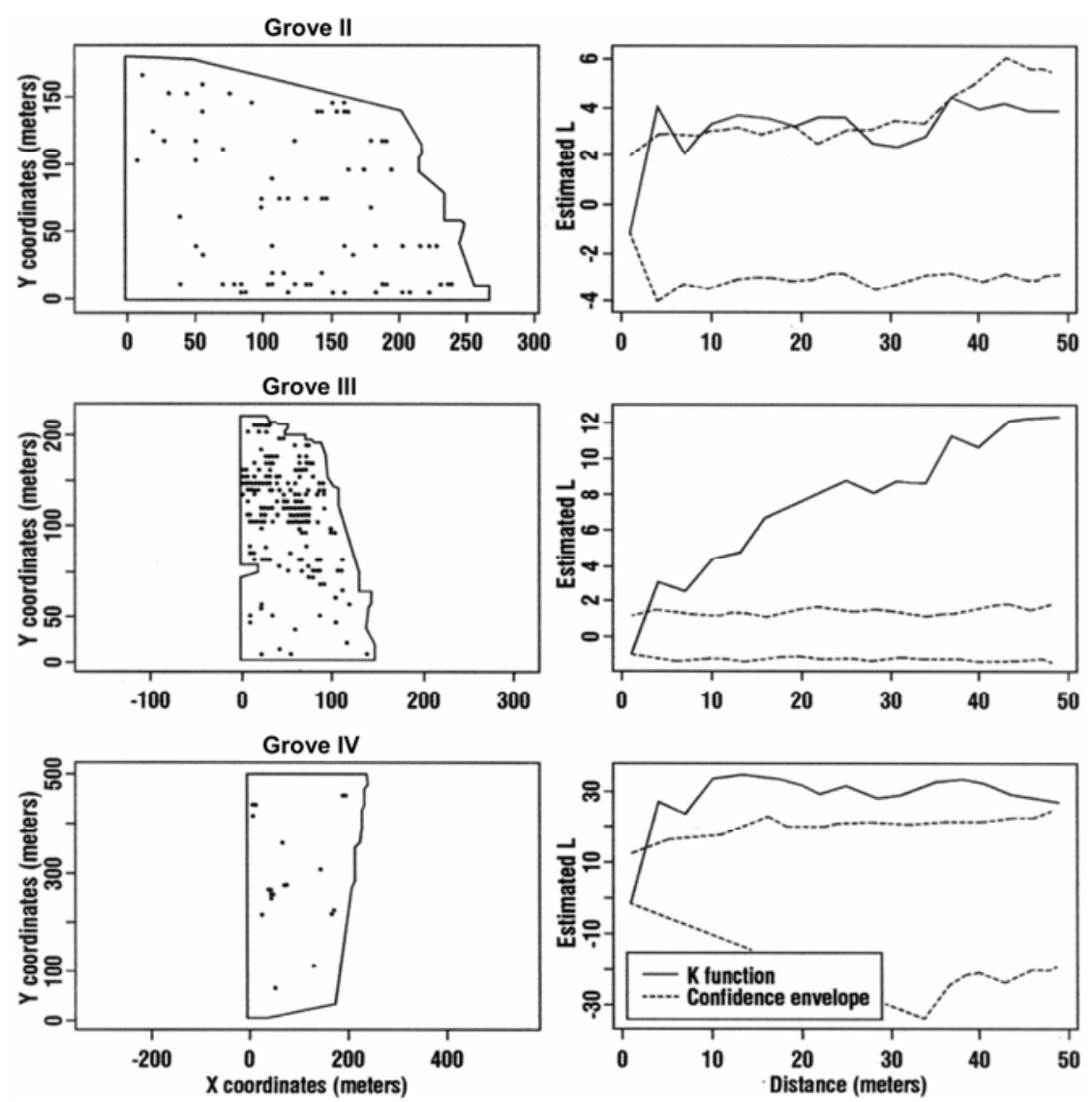

Fig. 2. Distribution of trees with fruit affected by citrus black spot, caused by Guignardia citricarpa, and Ripley's K function fit in groves II, III, and IV. Values above the confidence envelopes indicate aggregation. variance of the incidence of symptomatic trees in a particular area, and $k$ is the parameter of the negative binomial obtained by $k=x^{2} /\left(s^{2}-x\right)$. Greater aggregation is associated with a smaller $k$ and, thus, $n$ increases with aggregation (4). In the current work, the minimum sample size needed to estimate disease incidence was determined for each grove with a level of accuracy $C=20 \%$ (4).

\section{RESULTS}

Disease incidence varied from 0.6 to $84.9 \%$ in the assessed groves: $10.7 \%$ in $1999,22.7 \%$ in 2000 , and $84.9 \%$ in 2001 , for grove I; and 5.9, 17.5, and $0.6 \%$ for groves II, III, and IV, respectively. The quadrat with 49 trees ( 7 by 7) was the only one that consistently showed aggregation for the 3 years studied in grove I (Table 2). For grove II, three of nine different quadrat sizes showed values statistically higher than 1.0 , with the 6-by-6-tree quadrat showing the highest index of dispersion $(D)$, indicating aggregation (Table 3). For grove III, larger quadrat sizes resulted in higher values of $D$ for quadrats of 2 by 2 up to 10 by 10 . For grove IV, $D$ was significantly higher than 1.0 in all except the 10-by-10 quadrat size (Table 3). All groves showed aggregation for quadrats of the 36 to 49 trees, regardless of the disease incidence.

Using Ripley's K function, CBS aggregation was found for all groves (Figs. 1 and 2) as indicated by the $L(h)$ functions lying at least partially outside the simulation envelopes. The dependence among symptomatic trees varied from two to three neighboring trees.

The test for minimum mean distance $(d)$ also indicated aggregation for all years and groves studied, with the exception of grove I during 2001. In this case, the high incidence level interfered with the analysis (6). The $d$ values in grove $\mathrm{I}$ in 1999 and 2000 were 10.35 and $7.42 \mathrm{~m}(P=0.016$ and $0.001)$, respectively; $9.91 \mathrm{~m}(P=0.0013)$ for grove II; $6.22 \mathrm{~m}(P=0.0001)$ for grove III; and $24.70 \mathrm{~m}(P=0.0021)$ for grove IV. Except for grove IV, the minimum distances between symptomatic trees were close to the spacing between neighboring trees, indicating dispersion of the disease over short distances. The relatively large distance estimated in grove IV can be explained by the low incidence of the disease ( $0.6 \%$ symptomatic trees).

The minimum sample size needed to estimate disease incidence within each grove with $20 \%$ accuracy for grove I was $n=209$ trees in $1999, n=85$ in 2000, and $n=5$ in 2001. For groves II, III, and IV, the minimum sample size was $n=566,399$, and 4,171, respectively (Fig. 3). The relationship between the number of samples and disease incidence followed a negative exponential model (Fig. 4). The estimated number of samples was based on an area of 2,143 trees, which is the average number of trees including all six maps. Below 
a disease incidence of $15 \%$, the number of trees to be sampled increases exponentially as the incidence declines. Above this incidence, the recommended sample size is at least 285 trees, corresponding to $13 \%$ of the total of number of trees within the block.

\section{DISCUSSION}

Systematic behavior, such as aggregation, regularities, or randomness of symptomatic trees, analyzed by statistical methods for spatial point patterns has been used in other pathosystem studies (5). However, to our knowledge, this is the first time this methodology has been applied to the study of fungal disease of citrus.

The tests used to determine spatial aggregation of CBS vary in their approach, each having advantages and restrictions. We have used multiple approaches in order to ensure that the results are consistent with respect to the spatial patterns and not an artifact produced by a particular statistical method. For instance, tests based on $D$ depend on an arbitrary and subjective division of the sample areas into quadrats. This test does not take into account plant spacing. Therefore, a quadrat represents areas of different size if plant spacing is different. The alternative tests (Ripley's K function and $d$ ) do not operate under this assumption because they are based upon continuous spacing. Thus, they tend to behave better for larger areas because of the spacing of the plantings. The $d$ test is particularly useful to test for aggregation, which is generally the key hypothesis to be tested in epidemiological studies. The alternative tests are used to determine cluster size.

Results from three different analyses indicate aggregation of diseased trees, regardless of the incidence of the disease. Analyses based on the binomial index use the data variance on preestablished subareas within a sampling area (quadrats). Ripley's K function uses the data variance in different radii from each symptomatic tree (event) within the sampling area, defining a test function for several values of distance. The minimum distance method $(d)$ is based on a single test statistic.

Based on our analyses, trees with CBS were aggregated in small foci, with a maximum radius of $24.7 \mathrm{~m}$. Among the biological, physical, and environmental factors that could be involved for aggregation, the limitation of the pathogen inoculum dispersal over long distances seems to be the most important. According to Fitt et al. (8), "patterns of inoculum dispersal in crops may be examined by investigating patterns of disease spread." G. citricarpa can be dispersed by rain and wind. Aggregation is typical of splash-dispersal spores (20), such as conidia of G. citricarpa. Winddispersed ascospores probably are limited by tree architecture and height. All trees of the groves surveyed were 14 to 20 years old, with a minimum height of $3 \mathrm{~m}$, which reduces the air movement under the trees. Additionally, across rows, ascospores meet with obstacles in the form of plant foliage.

Hsiang et al. (13), working with a similar pathosystem, apple scab (caused by
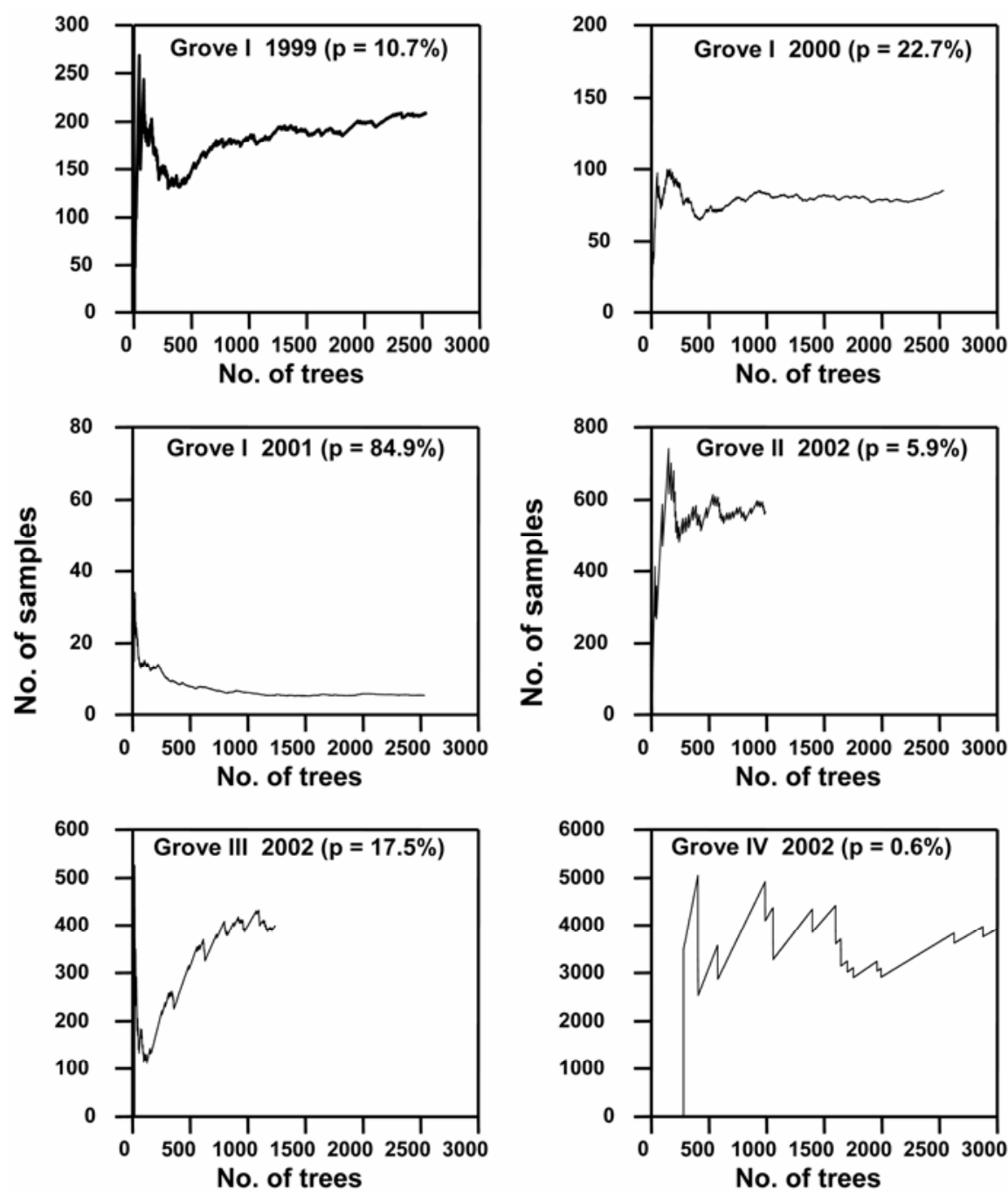

Fig. 3. Minimum number of sampled trees needed to estimate citrus black spot incidence, the percentage of trees with fruit affected by citrus black spot, caused by Guignardia citricarpa, in each assessment for different sampled groves.

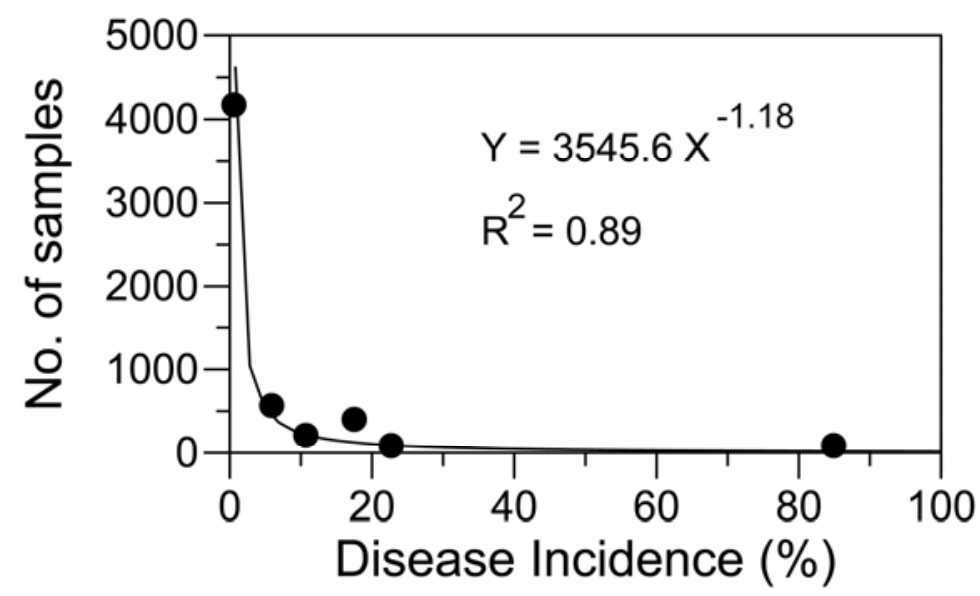

Fig. 4. Number of sampled trees used to estimate citrus black spot incidence, the percentage of trees with fruit affected by citrus black spot, caused by Guignardia citricarpa.
Venturia inaequalis), showed that the spatial pattern of this disease was aggregated within a radius of $20 \mathrm{~m}$. Kaplan (16), working with the same pathosystem, spores were dispersed within a distance of

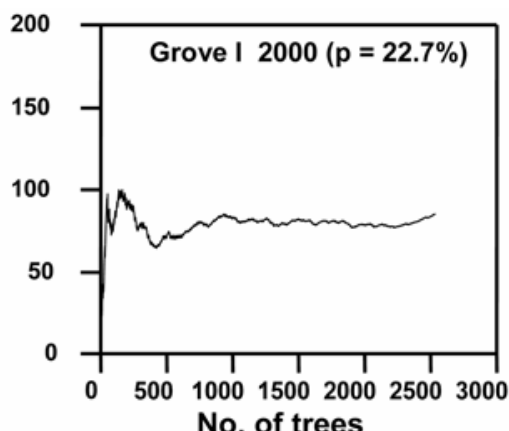


$6 \mathrm{~m}$. These two studies demonstrate that the short distance of dispersal of ascospores of apple scab contributed to aggregation in its spatial pattern. The size of $V$. inaequalis ascospores, 12 to 15 by 6 to 8 $\mu \mathrm{m}$ (26), is similar to those of G. citricarpa ascospores, which are 12.5 to 16 by 4.5 to $6.5 \mu \mathrm{m}$ (19). The way that ascospores of these two species are produced and released also is similar; thus, this may be the reason for the similar dispersal distances of $V$. inaequalis and G. citricarpa observed in this study.

Dispersal of pathogens impacts almost all aspects in the development of integrated pest management, from the foundation knowledge components to sampling strategies (3). Short-distance dispersion of $G$. citricarpa leads to the aggregation pattern of CBS. As a consequence, the number of trees needed to estimate disease incidence would be higher than for a random pattern.

\section{LITERATURE CITED}

1. Aguilar-Vildoso, C. I., Ribeiro, J. G. B., Feichtenberger, E., Goes, A., and Spósito, M. B. 2002. Manual técnico de procedimentos da mancha preta dos citros. Brasília: MAPA/SDA/DDIV.

2. Aylor, D. E. 1990. The role of intermittent wind in the dispersal of plant pathogens. Annu. Rev. Phytopathol. 28:73-92.

3. Aylor, D. E., and Irwin, M. E. 1999. Aerial dispersal of pests and pathogens: implications for integrated pest management. Agric. For. Meteorol. 97:233-234.

4. Campbell, C. L., and Madden, L. V. 1990. Introduction to Plant Disease Epidemiology. Wiley, New York

5. Charest, J., Dewdney, M., Paulitz, T., Philion, V., and Carisse, O. 2002. Spatial distribution of Venturia inaequalis airborne ascospores in orchards. Phytopathology 92:769-779.

6. Diggle, P. J. 2003. Statistical Analysis of Spatial Point Patterns. Academic University
Press, London.

7. Fagan, C., and Goes, A. 2000. Efeito da mancha preta dos frutos cítricos causada por Guignardia citricarpa nas características tecnológicas do suco de frutos de laranjeira 'Natal'e 'Valência'. (Abstr.) Summa Phytopathol. $26: 122$.

8. Fitt, B. D. L., McCartney, H. A., and Walklate, P. J. 1989. The role of rain in dispersal of pathogen inoculum. Annu. Rev. Phytopathol. 27:241-270.

9. FNP Consultoria \& Comércio. 2005. Agrianual 2005. Anuário da agricultura brasileira. FNP Consultoria \& Comércio, São Paulo, Brazil.

10. Gilligan, C. A. 1982. Statistical analysis of the spatial pattern of Botrytis fabae on Vicia faba: a methodological study. Trans. Br. Mycol. Soc. 79:193-200.

11. Goes, A., and Feichtenberger, E. 1993. Ocorrência da mancha preta causada por Phyllosticta citricarpa (Guignardia citricarpa) em pomares cítricos do Estado de São Paulo. Fitopatol. Bras. 15:73-75.

12. Gottwald, T. R., Cambra, M., Moreno, P., Camarasa, E., and Piquer, J. 1996. Spatial and temporal analyses of citrus tristeza virus in eastern Spain. Phytopathology 86:45-55.

13. Hsiang, T., Ma, X. L., and Zhou, T. 2000. Temporal and spatial analyses of genetic diversity in Venturia inaequalis assessed by RAPD markers. (Abstr.) Can. J. Plant Pathol. 22:186.

14. Huber, L., Madden, L. V., and Fitt, B. D. L. 1998. Rain-splash and spore dispersal: A physical perspective. Pages 348-370 in: Epidemiology of Plant Diseases. D. G. Jones, ed. Kluwer, Dordrecht, The Netherlands.

15. Hughes, G., Madden, L. V., and Munkvold, G. P. 1996. Cluster sampling for disease incidence data. Phytopathology 86:132-137.

16. Kaplan, J. D. 1986. Dispersal gradients and deposition efficiency of Venturia inaequalis ascospores and their relationship to lesion densities. Ph. D. thesis, University of New Hampshire, Durham.

17. Kenkel, N. C. 1988. Pattern of self-thinning in Jack Pine: testing the random mortality hypothesis. Ecology 69:1017-1024.

18. Klotz, L. J. 1978. Fungal, bacterial and non- parasitic diseases and injuries originating in the seedbed, nursery and orchard. Pages 1-66 in: The Citrus Industry. W. Reuther, E. C. Calavan, and G. E. Carman, eds. University of California, Berkeley.

19. Kotzé, J. M. 2000. Black spot. Pages 23-25 in: Compendium of Citrus Diseases. L. W. Timmer, S. M. Garnsey, and J. H. Graham, eds. American Phytopathological Society Press, St. Paul, MN.

20. Madden, L. V. 1992. Rainfall and dispersal of fungal spores. Pages 39-79 in: Advances in Plant Pathology. J. H. Andrews and I. Tommerrup, eds. Academic Press, London.

21. Madden, L. V., and Hughes, G. 1995. Plant disease incidence: distributions, heterogeneity, and temporal analysis. Annu. Rev. Phytopathol. 33:529-564.

22. Pedgley, D. E. 1986. Long distance transport of spores. Pages 346-365 in: Plant Disease Epidemiology. Population Dynamics and Management. K. J. Leonard and W. E. Fry, eds. MacMillan, New York.

23. R Development Core Team. 2004. R: A language and environment for statistical computing. R Foundation for Statistical Computing, Vienna, Austria. ISBN 3-90005100-3, www.Rproject.org.

24. Ripley, B. D. 1981. Spatial Statistics. John Wiley \& Sons, New York.

25. Rowlingson, B., and Diggle, P. 1993. Splancs: spatial point pattern analysis code in S-Plus. Comput. Geosci. 19:627:655.

26. Sivanesan, A., and Waller, J. M. 1974. Ventura inaequalis. No. 401. in: CMI Descriptions of Pathogenic Fungi and Bacteria. Commonw. Mycol. Inst./Assoc. Appl. Biol., Kew, Surrey, England.

27. Spósito, M. B. 2003. Dinâmica temporal e especial da mancha preta (Guignardia citricarpa) e quantificação de danos causados à cultura dos citros. Ph.D. thesis, Escola Superior de Agricultura "Luiz de Queiroz", Universidade de São Paulo, Piracicaba, Brasil.

28. Timmer, L. W. 1999. Diseases of fruit and foliage. Pages 107-123 in: Citrus Health Management. L. W. Timmer and L. W. Duncan, eds. American Phytopathological Society Press, MN. 